\title{
HUMAN IMPACT ON THE FUNCTIONING OF RIVER CHANNELS IN THE POLISH CARPATHIANS
}

DOI: http://dx.doi.org/10.18509/GBP.2019.23

UDC: $556.537: 502.1(438)$

\author{
Malgorzata Kijowska-Strugala \\ Institute of Geography and Spatial Organization, \\ Polish Academy of Sciences, Poland
}

\begin{abstract}
Human activities, apart from natural factors, play an important role in channels changes especially in mountain areas The main objective of the study was to assess the impact of human activities on the functioning of selected river channels in the Polish Western Carpathians in the last 50 years. The research showed a significant changes in the morphology of the river channels. There has been a general tendency to channel incision mainly due to floods, channel modification and land use/land cover changes (cultivated land abandonment and increase areas with forest and grassland). Channels incision was also observed below the dams. This was due to the reduced river load of bed and suspended sediment material, which was trapped in the reservoir, and the enhanced energy of the 'hungry water'. It was also found that the influence of reservoirs on the hydromorphological state of rivers below their location is diversified and not necessarily negative. In addition, suspended sediment load in small mountain stream in the period 1970-1999 decreased due to cultivated land abandonment. After that suspended sediment load increased as a result of the appearance of a new sediment sources associated with intensification of landslides and human activity, such as construction works. The results of this study can be used as a basis for to formulate policies and manage river systems in mountain areas.
\end{abstract}

Keywords: human activity, river channels, land use land cover changes, reservoirs, Polish Carpathians

\section{INTRODUCTION}

Human activities, apart from natural factors, play an important role in channels changes especially in mountain areas [1], [2], [3]. Several factors that control channels morphology have been recognized. One of the most important of them are channelization, gravel mining [4], [5] and dams construction [6]. Moreover, land use and land cover changes (LULCC) can also lead to a river channels changes [7], [8]. In the Polish Western Carpathians after Warld War II until the end of the 1980s, a continuous increase in population and dominance of agriculture in the structure of land use was recorded [9]. The collapse of the centrally planned economy in 1989 affected LULCC related to the abandonment of arable land in favour of forest and meadows [10], [11]. These changes have long-term and various consequences for the natural environment, that are mainly related to the reduction of erosion on the slopes [12]. Furthermore, cart tracks were abandoned and overgrown with shrubs, that influenced the change in the drainage of water and sediments supply to channels [13], [14]. A reflection of changes observed in the natural environment at the catchment is transport of suspended sediment in the river 
[15]. In addition, the construction and operation of reservoirs on rivers in the Carpathians has led to significant changes in the natural conditions of river channels and valleys.

The main objective of the study was to assess the impact of human activities on the functioning of selected river channels in the Polish Western Carpathians in the last 50 years. The main attention was paid to the dynamics of river channel beds, transport of the suspended sediment in the stream associated with LULCC, and assessment of the hydromorphological state of the rivers below and above reservoirs.

\section{STUDY AREA AND METHODS}

The study was conducted on the selected rivers in the Polish Western Carpathians (Fig. 1). Studied rivers are typical for the Beskidy Mountains. Flysch sediments, which were formed during the Cretaceous-Paleogene period, are predominant in the geological structure of the Carpathians. The hydrological regime of the Carpathian rivers is characterized by high seasonal, as well as small long-term, flow changeability. Low flows occur most often during the autumn and winter months, and high flows are most likely to occur in the spring and summer months [16].

The study conducted in the Polish Carpathians included:

i) analysis of the position of river channel beds based on the long-term observation series of daily water stages. Five rivers were chosen for this analysis: the Ochotnica river (Tylmanowa guging station: 1972-2011); the Kamienica Nawojowska river (Nowy Sącz gauging station: 1981-2014) and the Ropa, Zdynia and Wisłok rivers (Szymbark, Uście Gorlickie and Pastwiska gauging stations, respectively: 1972-2011) (Fig. 1). The data was provided by the Regional Water Management Board in Cracow.

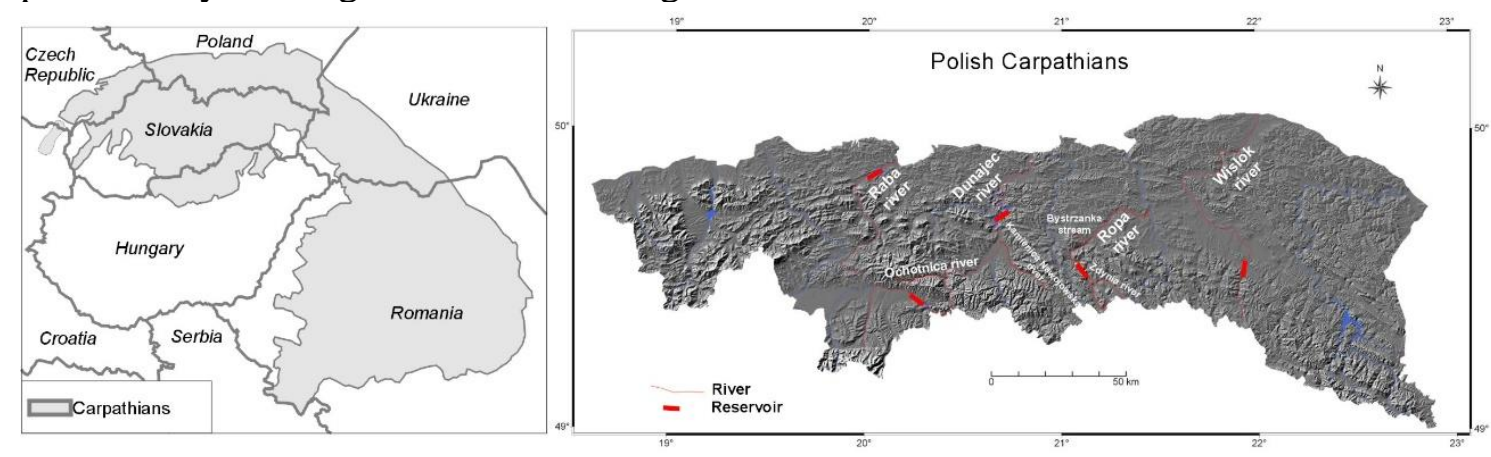

Figure 1. Study area

ii) changes in suspended sediment in the Bystrzanka stream in the period 1970-2017. This periods covered a LULCC (cultivated land decreased, forest and grassland increased). Principal component analysis (PCA) and Revised Universal Soil Loss Equation (RUSLE), [17] were used in the analysis.

iii) analysis of the hydromorphological state of the rivers above and below reservoirs. Four rivers have been selected: the Ropa, Raba, Dunajec and Wisłok rivers. The research was based on the British River Habitat Survey (RHS). The synthetic indices Habitat Quality Assessment (HQA) and Habitat Modification Score (HMS) were calculated on the basis of the data for each section studied; this allowed the hydromorphological properties of rivers to be assessed numerically. 


\section{RESULTS AND DISCUSSION}

\section{Dynamics of river channels}

Two main factors determine changes in the position of the rivers channel beds: natural (floods, tributaries, type of the channel bed substrate) and anthropogenic (e.g. control works in the channel, reservoir and LULCC). The erosion observed in the Carpathians rivers in the last decades have increased due to the economy transformation in the country, and in recent years, the Polish accession to the European Union.

On the basis of an analysis of the minimum water levels from 1972 to 2011, two periods can be identified with different tendencies in changing the position of the Ochotnica channel (Fig. 2). The first covers the period from 1972 to 1996, when aggradation (3.9 $\mathrm{cm} \mathrm{year}^{-1}$ ) was the predominant process, whereas from 1997 to 2011 incision $(3.2 \mathrm{~cm}$ year ${ }^{-1}$ ) dominated. It should be noted that despite the change in the trend of the level of the Ochotnica channel, there were no statistically significant changes in the floods frequency in the analyzed period [8]. Discharge analysis confirmed incision of the Ochotnica channel. In 1997, the lowest water level was $206 \mathrm{~cm}$, with a discharge of 0.81 $\mathrm{m}^{3} . \mathrm{s}^{-1}$, and in 2010 at the same water level the discharge recorded was $2.24 \mathrm{~m}^{3} \mathrm{~s}^{-1}$. This example showed that the same water level in the multiyear period corresponded to higher discharges, which was evidence of the river channel incision. The periods of the channel referred to the period of the centrally planned economy with a large share of cultivated land and incision referred to free market economy with a rapid decrease of arable land in Gorce catchments [8], [18].

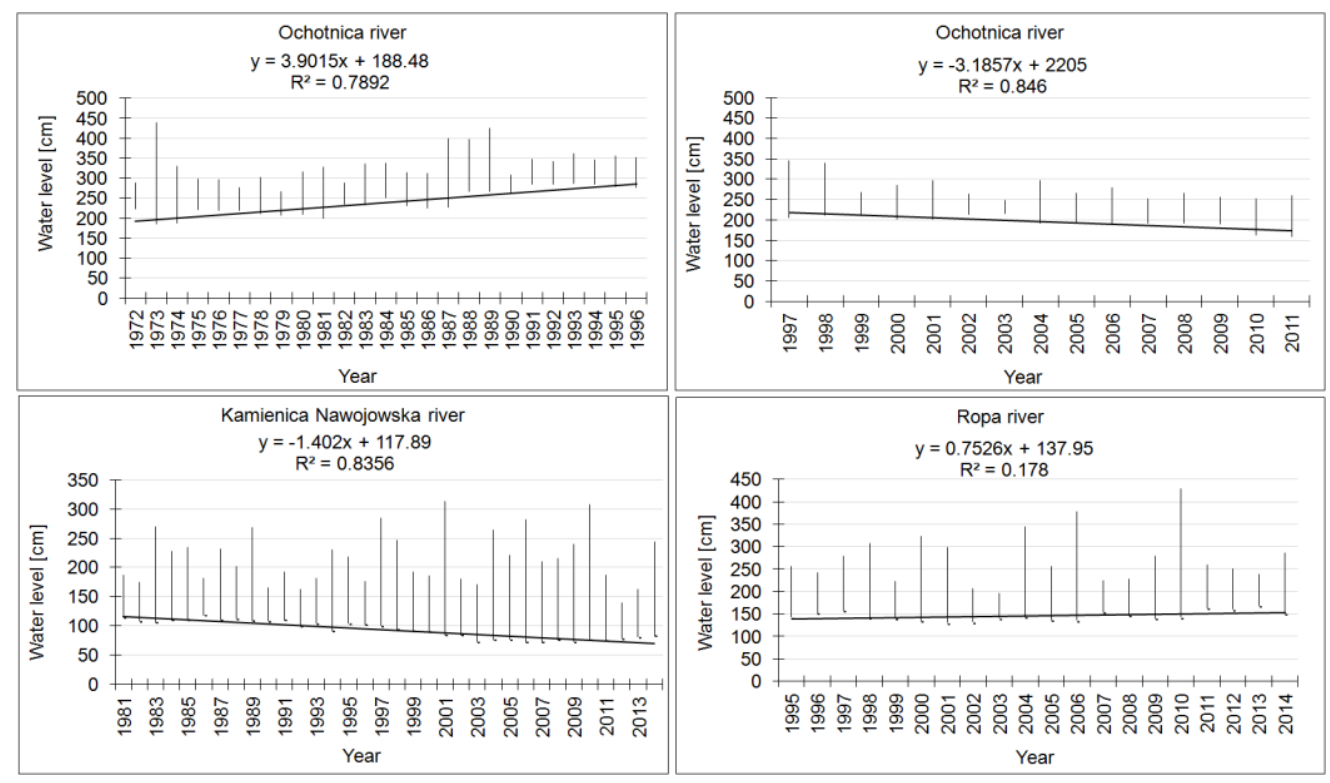

Figure 2. Minimum and maximum annual water level on the selected rivers (Ochotnica, Kamienica Nawojowska, Ropa) in the Polish Carpathians

The trend of the incision of the Ochotnica channel in recent years was compatible with the changes of the river channels level noted in the Beskidy Mountains [19]. In the Kamienica Nawojowska river the tendency of channel incision was observed starting from the 1960. Average annual rate of increase of the minimum stages was between 0.4 to $1.2 \mathrm{~cm}_{\text {year }}{ }^{-1}$. The average incision of the Zdynia riverbed was $2.2 \mathrm{~cm}_{\text {year }}{ }^{-1}$ and the Wisłok riverbed $0.3 \mathrm{~cm}_{\text {year }}^{-1}$. The lack of major changes in the Wisłok riverbed resulted from the channel lithology. 
The direct anthropogenic factor determining the direction and scale of changes in the morphology of the Carpathian river channels are reservoirs [20]. In the selected profiles located below the Klimkówka reservoir, the incision of the Ropa river channel was observed, reaching several dozen centimeters during one flood [20], [21]. The rate of channel incision depends on the number and size of floods, lithology, as well as the distance from the reservoir. The biggest changes were observed just below the reservoir.

\section{Land use land cover changes (LULCC) and suspended sediment transport}

In the Carpathians, during last 50 years an abandonment of cultivated land and increase of forest and grassland area has been noted [18]. In addition, in many Carpathian catchments observed the development of hydro-technical infrastructure and the channels regulation. These changes have influenced the transport of suspended sediment. Human impact is more diverse than other sources of sediment and can have significant short- and long-term effects. Many studies have documented LULCC as fundamental factors affecting soil erosion processes and sediment delivery into rivers [22], [23]. LULCC have reduced soil erosion in Bystrzanka catchment by $74 \%$ (based on RUSLE). Hydrometeorological data has not shown a statistically significant trend despite changes in forms of human activity in 1970-2017 [24]. In the first three decades of the analysed period (1970-1999), suspended sediment load gradually decreased. In 2010-2017, suspended sediment load was the highest in the whole investigated period. PCA confirmed that it was a result of the appearance of new sediment sources associated with intensification of landslides, channel erosion and new forms of human activity, such as construction works. The imposition on these factors resulted in an increase in suspended sediment load and masked the effects of rainfall and LULCC in the catchment [24].

\section{Hydromorphological state of rivers}

The construction of reservoirs leads to changes in the hydrological and thermal regime of rivers, the hydrochemical character of rivers, and the morphology of river valleys and riverbeds [25], [26], [27]. Despite the fact that the functioning of reservoirs causes changes in the natural biotic and abiotic elements of the river and valley habitat, the influence of reservoirs on the hydromorphological state of rivers below their location is diversified and not necessarily negative. Selected rivers in Carpathians above and below reservoirs indicate a low or acceptable habitat quality based on the HQA index. The habitat quality was mainly influenced by the number and diversification of natural morphological elements of bottoms and banks, the structure of bank vegetation. Level of modification of rivers habitat (based on HMS index) was classified as nearly natural, slightly modified by human activity (the Wisłok and the Dunajec rivers, above the reservoirs; the Ropa River, below the reservoir) and little changed (the Ropa River, above the reservoir; the Dunajec River, below the reservoir). The habitat quality in the Raba River above and below reservoir was considerably changed. In the Ropa river below the reservoir was observed better hydromorphological state than above the reservoir mainly due to greater diversification of natural morphological elements of the channel and flow types and lack of riverbank reinforcements. Much change habitat on the Raba river above and below reservoir, were caused by the anthropogenic modification of channel banks, i.e., bank reinforcements and reprofiling. The channel of the Raba river was regulated to

protect against bank erosion. Below reservoir the channel modification noted was mainly due to stabilize the dam. Also in the Dunajec river bank reinforcements was observed. However, those modifications do not result directly from the influence of the reservoir. 
The regulation was to protect the road built along the river, and it was carried out long before the construction of the reservoir complex [28].

\section{CONCLUSIONS}

Functioning of river channels in the Polish Western Carpathians is associated with natural factors and in recent years, with human activities. Human activity modifies fluvial dynamics both directly and indirectly.

The research showed:

i) significant changes in the morphology of the river channels. There has been a general tendency to channel incision. These changes were influenced, among others floods and LULCC, especially cultivated land abandonment. In addition, it has been shown that the reservoir intensifies the tendency of incision especially below the dam. The impact of reservoir on channel incision decrease with the increasing distance from the reservoir.

ii) that the transition from a centrally planned to free market economy system and Poland's accession to the European Union changed the intensity and forms of impact of anthropogenic factors in the Polish Western Carpathians, which was reflected in the change of sources of the suspended sediment. The increase of suspended sediment load in recent years has been a result of the appearance of new sediment sources associated with landslides hotspot, channel erosion and construction works.

iii) that the hydromorphological state of the selected Carpathian rivers above and below reservoirs depends mostly on the natural habitat features of the area through which the rivers flow and the human activity near and in the river channels.

The results of the research underline the human impact on the functioning of the channels and can be used as a basis for to formulate policies and manage river systems in mountain areas.

\section{REFERENCE}

[1] Starkel L. Change in the frequency of extreme events as the indicator of climatic change in the Holocene (in fluvial systems), Quaternary International, vol. 91, pp 25-32, 2002.

[2] Krzemień K., Gorczyca E., Sobucki M., Liro M., Łyp M. Effects of environmental changes and human impact on the functioning of mountain river channels, Carpathians, southern Poland, Annals of Warsaw University of Life Sciences, Land Reclamation, vol. 47, pp 249-260, 2015.

[3] Stoffel M., Wyżga B., Marston R.A. Floods in mountain environments: a synthesis, Geomorphology, vol. 272, pp 1-9, 2016.

[4] Korpak J., Krzemień K., Radecki-Pawlik A. Wpływ budowli regulacyjnych i poboru rumowiska na koryta rzek i potoków górskich-wybrane przykłady z rzek karpackich, Gospodarka Wodna, pp 274-281, 2009.

[5] Zawiejska J., Wyżga B. Twentieth-century channel change on the Dunajec River, southern Poland: patterns, causes and controls, Geomorphology vol. 117, pp 234-246, 2010.

[6] Wiejaczka Ł., Olędzki J.R., Bucała-Hrabia A., Kijowska-Strugała M. A spatial and temporal analysis of land use changes in two mountain valleys: with and without dam reservoir (Polish Carpathians), Quaestiones Geographicae, vol. 36(1), 129-137, 2017.

[7] Wyżga B., Kundzewicz Z.W., Konieczny R., Piniewski M., Zawiejska J., Radecki-Pawlik A. Comprehensive approach to the reduction of river flood risk: Case study of the Upper Vistula Basin, Science of The Total Environment, vol. 631, pp 1251-1267, 2018.

[8] Kijowska-Strugała M., Bucała A. Flood types in a montain catchment: the Ochotnica river, Poland, Acta Geographica Slovenica -Geografski Zbornik, vol. 59, pp 23-36, 2019. 
[9] Kijowska-Strugała M., Bucała-Hrabia A., Demczuk P. Long-term impact of land use changes on soil erosion in an agricultural catchment (the Western Polish Carpathians), Land Degradation and Development, vol. 29, pp 1871-1884, 2018.

[10] Kozak J. Zmiany powierzchni lasów w Karpatach Polskich na tle innych gór świata. Uniwersytet Jagielloński, Kraków, 2005.

[11] Wyżga B., Zawiejska J., Radecki-Pawlik A., Hajdukiewicz H. Environmental change, hydromorphological reference conditions and the restoration of Polish Carpathian rivers, Earth Surface Processes and Landforms, vol. 37, pp 1213-1226, 2012.

[12] Kijowska-Strugała M., Demczuk P. Impact of land use changes on soil erosion and deposition in a small Polish Carpathians catchment in last 40 years, Carpathian Journal of Earth and Environmental Sciences, vol. 10, pp 261-270, 2015.

[13] Lach J., Wyżga B. Channel incision and flow increase of the upper Wisłoka River, southern Poland, subsequent to the reafforestation of its catchment, Earth Surface Processes and Landforms, vol. 27, pp 445-462, 2002.

[14] Kroczak R., Fidelus-Orzechowska J., Bucała-Hrabia A., Bryndal T. Land use and land cover changes in small Carpathian catchments between the mid-19 th and early 21 st centuries and their record on the land surface. Journal of Mountain Science, vol. 15, pp 2561-2578, 2018.

[15] Walling D.E. The impact of global change on erosion and sediment transport by rivers: current progress and future challenges. Scientific UNESCO, France, 2009.

[16] Chełmicki W., Skąpski R. Soja R. Reżim hydrologiczny rzek karpackich w Polsce, Folia Geographica, Series Geographica-Psyhica, pp 29-30, 1998-1999.

[17] Wischmeier W.H, Smith D. Predicting Rainfall Erosion Loss: A Guide to Conservation Planning. USDA Agricultural Handbook. US Department of Agriculture, Washington, DC, 1978.

[18] Bucała-Hrabia A. Long-term impact of socio-economic changes on agricultural land use in the Polish Carpathians. Land Use Policy, vol. 64, pp 391-404, 2017

[19] Wiejaczka Ł., Kijowska-Strugała M. Dynamics of the channel beds level in mountain rivers in the light of the minimum water stages analysis, Carpathian Journal of Earth and Environmental Sciences, vol. 10, pp 105-112, 2015.

[20] Wiejaczka Ł., Bochenek W. Przekształcanie dna koryta rzeki górskiej w czasie dużych wezbrań na przykładzie Ropy, Prace Geograficzne IGiPZ PAN, vol. 132, pp 27-38, 2013.

[21] Kijowska-Strugała M., Wiejaczka Ł., Gil E., Bochenek W., Kiszka K. The impact of extreme hydro-meteorological events on the transformation of mountain river channels (Polish Flysch Carpathians), Zeitschrift für Geomorphologie, vol. 61, no. 1, pp 75-89, 2017.

[22] García-Ruiz J.M., Reguiés D., Alvera B., Lana-Renault N., Serrano-Muela P., Nadal-Romero E., Navas A., Latron J., Martí-Bono C., Arnáez J. Flood generation and sediment transport in experimental catchments affected by land use changes in the Central Pyrenees, Journal of Hydrology, vol. 356, pp 245-260, 2008.

[23] Pietroń J., Chalov S.R., Chalova A.S., Alekseenko A.V., Jarsjö J. Extreme spatial variability in riverine sediment load inputs due to soil loss in surface mining areas of the Lake Baikal basin, Catena, vol. 152, pp 82-93, 2017.

[24] Kijowska-Strugała M. Sediment variability in a small catchment of the Polish Western Carpathians during transition from centrally planned to free-market economics, Geomorphology, vol, 325, pp 119-129, 2019.

[25] Kędra M., Wiejaczka Ł., Wesoły K. The role of reservoirs in shaping the dominant cyclicity and energy of mountain river flows, River Research and Applications, vol. 32, pp 561-571, 2015. 
[26] Wiejaczka Ł., Kijowska-Strugała M., Pierwoła P., Nowak M. Water temperature dynamics in a complex of reservoirs and its effect on the temperature patterns of a mountain river, Water Resources, vol. 45, pp 846-857, 2018.

[27] Kijowska-Strugała M., Wiejaczka Ł., Cebulski J., Kiszka K., Maślanka M., Kramkowska D.M. Factors affecting bluff development around a mountain reservoir: a case study in the Polish Carpathians, Geografiska Annaler: series A, vol. 101, pp 79-93, 2019.

[28] Wiejaczka Ł., Kijowska-Strugała M. Assessment of the hydromorphological state of Carpathian rivers above and below reservoirs, Water and Environment Journal, vol. 29, no. 2, pp 277-287, 2015. 